\title{
FORMULASI MEDIA PRODUKSI JAMUR TIRAM (Pleurotus ostreatus) DENGAN SUPLEMENTASI AMPAS SAGU
}

\section{Media Formulation Of Oyster Mushroom Production (Pleurotus Ostreatus) With Sago Pulp Supplementation}

\author{
Sri Utami, Umrah*, dan I Nengah Suwastika \\ Jurusan Biologi Fakultas Matematika dan IImu Pengetahuan Alam Universitas Tadulako Tondo \\ Palu, Sulawesi Tengah 94118
}

Keywords:

Oyster

mushroom, sago pulp, protein content and biological efficiency

Kata Kunci: Jamur tiram, Ampas sagu, Kadar protein, Efisiensi biologi

\begin{abstract}
This study aims to know the basic media with sago pulp supplementation which can be formulated into a medium for producing white oyster mushrooms and also to know the comparison of the right media and supplements in the formulation to give maximum oyster mushrooms production. In this study using a comparison with sawdust substrate and sago pulp to see how effective the sago pulp substrate as a supplement media for the oyster mushroom production. the program used is experimental designed in Completely Randomized Design (CRD), consists of three replications so that twelve experiments were obtained. The treatment arrangement is M1: Base media without supplements (controls), M2: $90 \%$ base media $+10 \%$ sago pulp, M3: $80 \%$ basic media $+20 \%$ sago pulp, M4: base media $70 \%$ + sago pulp $30 \%$. The observation parameters used in the study are mycelium growth, fruit body growth, biological efficiency and measurement of protein levels in the fruit body of the oyster mushroom. The results showed that the addition of sago pulp in the media of oyster mushroom production had no effect on the growth of oyster mushrooms. This can be seen from the media of production of M1 (without the addition of sago pulp) experiencing a higher growth rate of mycelium compared to other treatments. The addition of sago pulp has an effect on the levels of oyster mushroom protein. This can be seen from the protein content of oyster mushrooms in M2 production media which have high protein content. Normal levels of white oyster mushrooms in sawdust media range from $18 \%-20 \%$. This is due to the mixing of wood powder as a production medium and $10 \%$ sago pulp as supplementation to produce more nutrient levels.
\end{abstract}

\begin{abstract}
ABSTRAK
Penelitian ini bertujuan untuk mengetahui media dasar dengan suplementasi ampas sagu dapat diformulasi menjadi media produksi jamur tiram putih (Pleurotus ostreatus) serta untuk mengetahui dosis perbandingan media dasar dan suplemen dalam formulasi untuk memberikan produksi jamur tiram putih ( $P$. ostreatus) yang maksimal. Dalam penelitin ini menggunakan perbandingan dengan substrat serbuk gergaji dan ampas sagu untuk melihat seberapa efektif substrat ampas sagu sebagai suplemen media produksi jamur tiram. Rancangan yang digunakan adalah eksperimental yang didesain dalam Rancangan Acak Lengkap (RAL), terdiri dari tiga kali ulangan sehingga diperoleh dua belas kali percobaan. Susunan perlakuan adalah M1 : Media dasar tanpa suplemen (kontrol), M2 : media dasar 90\% + ampas sagu 10\%, M3 : media dasar $80 \%$ + ampas sagu $20 \%$, M4 : media dasar $70 \%$ + ampas sagu $30 \%$. Parameter pengamatan yang digunakan dalam penelitian adalah pertumbuhan miselium, pertumbuhan tubuh buah, efisiensi biologi dan pengukuran kadar protein pada tubuh buah jamur tiram. Hasil penelitian menunjukkan bahwa penambahan ampas sagu dalam media produksi jamur tiram tidak berpengaruh untuk pertumbuhan jamur tiram. Hal ini dapat dilihat dari media produksi M1 (tanpa penambahan ampas sagu) mengalami laju pertumbuhan miselium yang lebih tinggi dibandingkan dengan perlakuan lain. Penambahan ampas sagu berpengaruh pada kadar protein jamur tiram. Hal ini dapat dilihat dari kandungan protein jamur tiram pada media produksi M2 memiliki kandungan protein yang tinggi. Kadar normal jamur tiram putih pada media serbuk gergaji berkisar $18 \%-20 \%$. Hal ini disebabkan karena adanya pencampuran serbuk kayu sebagai media produksi dan ampas sagu $10 \%$ sebagai suplementasi sehingga menghasilkan kadar nutrient yang lebih banyak.
\end{abstract}

Corresponding Author : umrah.mangonrang62@gmail.com 


\section{PENDAHULUAN}

Jamur tiram putih merupakan bahan pangan yang sudah dikenal oleh masyarakat sebagai salah satu sumber gizi keluarga. Saat ini jamur yang sangat populer untuk dikonsumsi oleh masyarakat luas diantaranya adalah jamur tiram dan jamur merang. Jamur tersebut mudah untuk dibudidayakan dan mempunyai nilai ekonomi tinggi, sehingga prospektif sebagai sumber pendapatan petani (Suparti dan Karimawati, 2017).

Jamur tiram merupakan salah satu produk holtikultura yang dapat kembangkan kearah produksi (Wardana dan Erdiansyah, 2016). Jamur tiram dapat menjadi salah satu komoditas unggulan dalam sektor pertanian yang diminati dipasaran karena memiliki kandungan gizi yang tinggi dan nutrisi yang baik.

Jamur tiram memiliki sumber protein nabati yang tidak mengandung kolesterol dan memiliki kandungan gizi yang sangat tinggi sehingga aman untuk dikonsumsi setiap orang. Kandungan protein jamur tiram putih berkisar $21 \%$ lebih tinggi dibandingan jenis sayuran bayam $(5,5 \%)$, kubis $(4 \%)$, dan buncis $(4,2)$ ataupun daging sapi $(0,3 \%)$ (Damayanti dkk, 2014).

Substrat altenatif yang dapat dijadikan sebagai media pertumbuhan jamur tiram yaitu ampas sagu akan tetapi perlu dikaji terlebih dahulu pengaruhnya terhadap pertumbuhan dan produksi jamur tiram putih. Menurut Yuanita (2009), ampas sagu merupakan limbah yang didapatkan pada proses pengolahan tepung sagu dan merupakan salah satu serat pangan.

Media ampas sagu dipilih karena mempunyai kandungan nutrisi $64,6 \%$ pati dan sisanya $14 \%$ serat kasar, 3,3\% protein kasar, 0,3\% lemak, dan 5,0\% abu (Juwita dkk, 2013). Ampas sagu mengandung residu lignin sebesar $21 \%$, sedangkan kandungan selulosa di dalamnya sebesar $20 \%$ dan sisanya merupakan zat ekstraktif dan abu. Selain itu ketersediaan ampas sagu juga banyak dan belum dimanfaatkan secara optimal.

Penelitian ini memanfaatkan ampas sagu yang didapatkan dari petani sagu, karena banyaknya limbah yang hanya dibuang begitu saja dan belum dimanfaatkan secara optimal oleh petani lokal. Penggunaan media formulasi ampas sagu ini juga dapat memudahkan petani jamur tiram ketika serbuk gergaji sudah jarang ditemukan.

\section{BAHAN DAN METODE}

Rancangan yang digunakan adalah eksperimental yang desain dalam Rancangan Acak Lengkap (RAL), terdiri dari tiga kali ulangan sehingga diperoleh dua belas kali percobaan. Susunan perlakuan adalah :

$\mathrm{M}_{1}=$ Media dasar tanpa suplemen (kontrol) $\mathrm{M}_{2}=$ Media dasar $90 \%+$ ampas sagu $10 \%$ 
$\mathrm{M}_{3}=$ Media dasar $80 \%+$ ampas sagu $20 \%$

$\mathrm{M}_{4}=$ Media dasar $70 \%+$ ampas sagu $30 \%$

Keterangan :

$\mathrm{M}_{1}$ = Media dasar (serbuk gergaji + bekatul + kapur) 1000 gram

$\mathrm{M}_{2}=$ Media dasar 900 gram + ampas sagu 100 gram

$M_{3}=$ Media dasar 800 gram + ampas sagu 200 gram

$\mathrm{M}_{4}=$ Media dasar 700 gram + ampas sagu 300 gram

\section{PROSEDUR KERJA}

\section{Pembersihan dan pengayakan media}

Ampas sagu dan serbuk gergaji yang sudah dikumpulkan kemudian dijemur terlebih dahulu selama 7 hari, setelah itu diayak menggunakan ayakan $4 \mathrm{~mm}$. Tujuan dari pengayakan yaitu untuk memperoleh ukuran media yang seragam.

\section{Pencampuran media}

Media bahan dasar yang telah disediakan dicampur dengan suplemen ampas sagu dengan jumlah persen yang berbeda. Selanjutnya ditambahkan dengan air sebanyak yang secukupnya pada setiap perlakuan untuk mencapai total kandungan kadar air mencapai $60-65 \%$.

\section{Pemeraman media}

Pemeraman adalah proses pelapukan bahan yang dilakukan dengan cara membumbun campuran media kemudian menutupinya dengan karung selama 1 x 24 jam. Tujuannya mengurai senyawa-senyawa kompleks dengan bantuan mikroba agar diperoleh senyawasenyawa yang lebih sederhana, sehingga lebih mudah dicerna oleh jamur dan memungkinkan pertumbuhan jamur yang lebih baik.

\section{Pengisian media (pembungkusan)}

Pembungkusan menggunakan plastik baglog jamur yang tahan panas setiap baglog. Pengisian baglog sebanyak $1 \mathrm{~kg} /$ plastik, kemudian dipadatkan dengan bantuan botol atau alat lain. Setelah media dipadatkan, dipasangkan cincin dari paralon atau plastik pada bagian leher plastik sehingga menyerupai botol. Agar ukuran media seragam, sebaiknya media ditimbang saat pengisian.

\section{Sterilisasi media produksi}

Sterilisasi baglog dilakukan dengan menggunakan tungku permanen dan drum sebagai wadah yang bertujuan menginaktifkan mikroba, bakteri, kapang, maupun khamir yang dapat mengganggu pertumbuhan jamur yang ditanam. Sterilisasi dilakukan pada suhu $100^{\circ}-150^{\circ} \mathrm{C}$ selama 3 jam. Kemudian didinginkan selama 1 hari sebelum pemberian bibit.

\section{Inokulasi}

Inokulasi dilakukan dengan membuka kertas penutup baglog dan ujung baglog didekatkan pada bunsen kemudian bibit jamur F2 dimasukkan lewat cincin paralon bagian tengah dalam media. Bibit jamur tiram dimasukkan ke dalam lubang terebut sebanyak 5 gram. Setelah inokulasi kertas ditutup kembali dengan kertas sambil didekatkan ke bunsen. Selama proses 
inokulasi ruangan dan peralatan yang digunakan harus dalam keadaan steril. Sterilisasi peralatan dapat dilakukan dengan cara menyemprotkan peralatan dengan alkohol dan melidahapikan dibunsen sebelum menggunakannya.

Inkubasi (masa pertumbuhan jamur tiram) Inkubasi baglog jamur tiram dilakukan didua ruangan. Ruangan pertama dengan suhu $25^{\circ}-27^{\circ} \mathrm{C}$, inkubasi ini dilakukan hingga seluruh media (baglog) berwarna putih (ditumbuhi miselium) memenuhi baglog secara merata. Setelah

\section{HASIL}

\section{Laju Pertumbuhan Miselium}

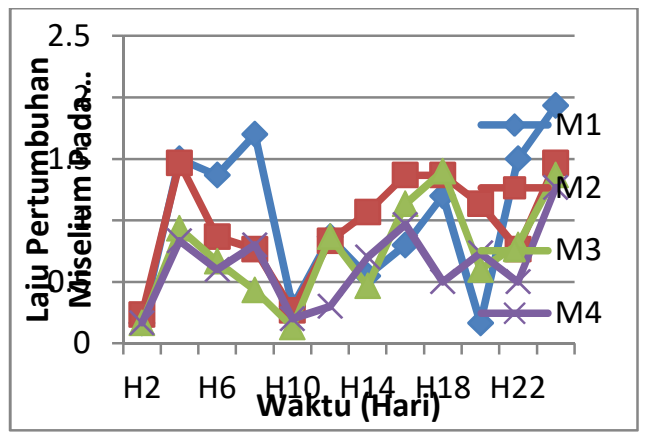

Gambar 1 Rata-rata laju pertumbuhan miselium jamur tiram (Pleurotus ostreatus) pada media formulasi setiap perlakuan.

Laju pertumbuhan miselium jamur tiram (Pleurotus ostreatus) pada baglog dengan perlakuan berbeda setiap baglog yang terdiri dari media dasar serbuk gergaji, dedak padi, kapur, dan ampas sagu. Pertumbuhan miselium diukur selama miselium memenuhi baglog akan dipindahkan ke kumbung dengan suhu $20^{\circ}-$ $24^{\circ} \mathrm{C}$, untuk pemeliharaan munculnya pinhead sampai munculnya tubuh buah.

Parameter yang diamati pertumbuhan miselium, pertumbuhan tubuh buah, efisiensi biologi dan kadar protein. Data-data yang diperoleh akan dianalisis melalui One Way anova dengan menggunakan soft ware "Statistika versi 7", bilamana terjadi perbedaan yang signifikan antar perlakuan, akan dilanjutkan dengan Uji berganda DMRT.

setiap dua hari sekali sampai miselium memenuhi salah satu baglog.

Berdasarkan grafik diatas (Gambar 1), pengukuran miselium dilakukan selama 24 hari dengan perlakuan yang berbeda pada masinng-masing baglog. Pada perlakuan M1 (media produksi tanpa penambahan ampas sagu) memiliki nilai rata-rata tertinggi yakni $0,081 \mathrm{~cm} / 2$ hari sedangkan untuk nilai rata-rata terendah terdapat pada perlakuan M4 dengan nilai $0,053 \mathrm{~cm} / 2$ hari.

\section{Masa Inkubasi Miselium Jamur Tiram Putih Memenuhi Baglog}

Nilai rata-rata masa inkubasi miselium jamur tiram putih yang memenuhi media baglog. Pertumbuhan miselium pada perlakuan M2 paling cepat memenuhi media baglog dengan nilai rata-rata 59,6. Sedangkan pada perlakuan M3 
pertumbuhan miselium memenuhi media baglog paling lama dengan nilai rata-rata 83,3 .

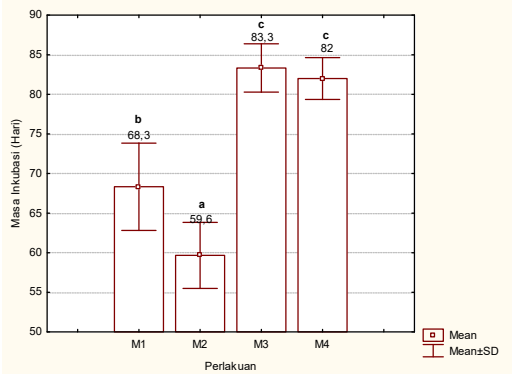

Gambar 2 Grafik masa inkubasi miselium jamur tiram putih memenuhi baglog

\section{Berat Segar Jamur Tiram Putih ( $P$. ostreatus)}

Produksi berat segar jamur tiram yang tertinggi dengan rata-rata 82 gram terdapat pada perlakuan M1. Sedangkan untuk berat segar terendah terdapat pada perlakuan M4 dengan nilai rata-rata 27 gram.

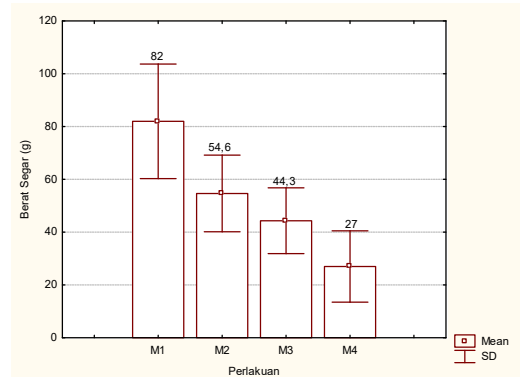

Gambar 3 Grafik bobot berat segar jamur tiram (Pleurotus ostreatus) pada media formulasi setiap perlakuan.

\section{Berat Kering Jamur Tiram}

Grafik (Gambar4) menunjukkan bobot kering tertinggi dan terendah. Perlakuan M1 merupakan bobot berat kering tertinggi dengan nilai 11 gram sedangkan untuk bobot terendah yaitu perlakuan M4 dengan nilai 5 gram.

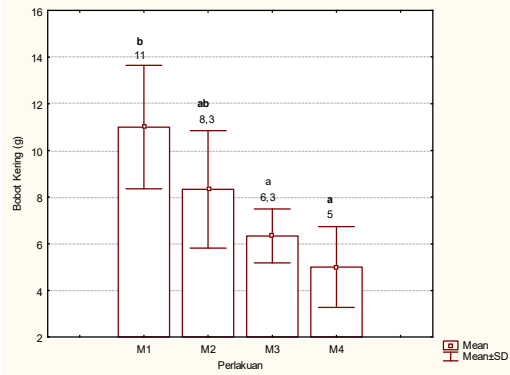

Gambar 4 Grafik bobot berat kering jamur tiram (Pleurotus ostreatus) pada media formulasi setiap perlakuan

\section{Efisiensi Biologi}

Berdasarkan hasil analisis sidik ragam nilai efisiensi biologi menunjukkan bahwa M1 memiliki nilai tertinggi dari semua perlakuan yaitu 38\%. Sedangkan untuk nilai efisiensi biologi terendah pada perlakuan M3 29\%.

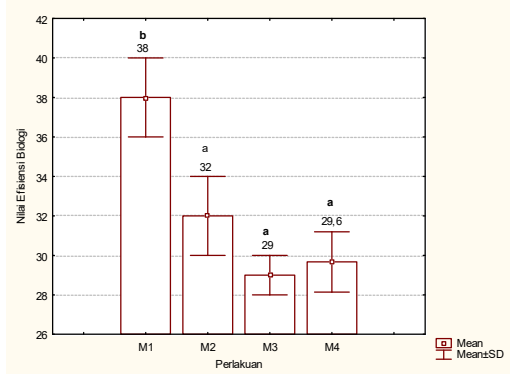

Gambar 5 Grafik nilai efisiensi biologi jamur tiram (Pleurotus ostreatus) pada media formulasi setiap perlakuan. 


\section{Kadar Protein}

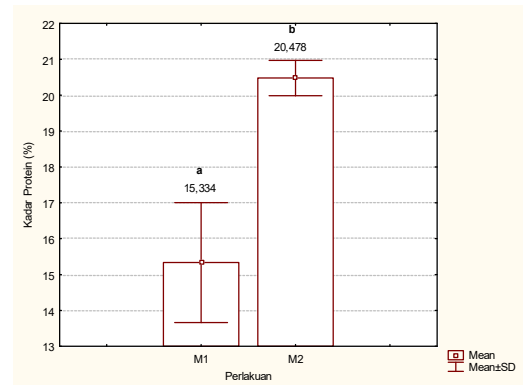

Gambar 6 Grafik kadar protein jamur tiram (Pleurotus ostreatus) pada media formulasi setiap perlakuan.

Pada analisis sidik ragam diatas menunjukkan kadar protein jamur tiram tertinggi pada M2 dengan nilai 20,5\% sedangkan M1 memiliki nilai terendah dengan nilai $15,2 \%$.

\section{PEMBAHASAN}

Jamur tiram putih ( $P$. ostreatus) merupakan organisme yang tidak dapat menyediakan makanan sendiri dengan cara berfotosintesis, jamur mengambil atau menyerap zat-zat makanan melalui organisme yang lain untuk memenuhi kebutuhanan hidupnya sehingga bersifat heterotrofik. Jamur cocok ditumbuhkan dengan berbagai serbuk gergaji kayu karena dapat memacu pertumbuhan miselium jamur lebih cepat pada media (Sumarni dkk, 2009).

Hasil rata-rata laju pertumbuhan miselium berdasarkan analisis sidik ragam (Gambar 4.1) menunjukkan terdapat adanya perbedaan terhadap setiap perlakuan. Pertumbuhan miselium jamur diukur menggunakan penggaris pada media produksi (baglog) setiap 2 hari sekali sampai memenuhi media. Media produksi M1 (media tanpa penambahan ampas sagu) mempunyai laju pertumbuhan miselium tertinggi dibandingkan dengan perlakuan lainnya dengan nilai rata-rata $0,081 \mathrm{~cm} /$ hari.

Pada media produksi M2 (media dengan penambahan ampas sagu 10\%) memiliki rerata laju pertumbuhan miselium yaitu 0,065 cm/hari, M3 (media dengan penambahan ampas sagu 20\%) memiliki rerata laju pertumbuhan miselium yaitu ratarata 0,061, sedangkan M4 (media dengan penambahan ampas sagu 30\%) memiliki rerata laju pertumbuhan miselium yang paling rendah yaitu $0,053 \mathrm{~cm} /$ hari. Penambahan ampas sagu pada media produksi tidak berpengaruh pada laju pertumbuhan miselium jamur tiram $(P$. ostreatus). Hal ini disebabkan dosis pemberian ampas sagu melebihi dosis yang dibutuhkan untuk merangsang pertumbuhan miselium.

Pertumbuhan miselium ditandai dengan munculnya warna putih seperti kapas yang tumbuh menyebar pada permukaan media baglog. Miselium jamur harus berwarna putih dan tumbuh jaringan inokulasi (Riyanto, 2010). Pertumbuhan dan perkembangan jamur membutuhkan nutrisi 
dalam bentuk selulosa, lignin, glukosa, protein dan senyawa pati (Kinasih, 2015). Bila kandungan nutrisi cukup, miselium jamur akan tumbuh secara normal. Menurut Utama (2013), kandungan nutrisi yang terdapat pada media produksi merupakan salah satu faktor yang dapat mempengaruhi pertumbuhan miselium jamur. Jamur membutuhkan karbon, nitrogen, vitamin dan mineral untuk pertumbuhannya.

Selain itu, pertumbuhan miselium pada jamur dipengaruhi oleh beberapa faktor meliputi faktor fisik, kimia, dan biologi. Faktor fisik terdiri dari suhu, $\mathrm{pH}$, kelembaban, intensitas cahaya, dan sirkulasi udara. Kisaran $\mathrm{pH}$ yang dibutuhkan selama pertumbuhan miselium jamur berkisar 4 - 7. $\mathrm{pH}$ (tingkat keasaman) akan mempengaruhi pertumbuhan secara langsung terhadap permukaan sel jamur pada ketersediaan nutrisi. Menurut Patmasari (2007), pH yang optimal bagi pertumbuhan miselium jamur media produksi berkisar 6,2 - 7.

Media dengan penambahan kandungan ampas sagu $10 \%$ dapat dimanfaatkan sebagai media pertumbuhan jamur tiram putih. Akan tetapi, komposisi penggunaan ampas sagu harus diperhatikan dalam pencampuran media produksi. Hal tersebut disebabkan karena tingginya kandungan pati dalam ampas sagu yang menghambat penyebaran miselium pada masa inkubasi. Kandungan pati pada ampas sagu sebanyak $64,4 \%$ (Juwita dkk, 2010). Selain itu, pembentukan pati ampas sagu juga dipengaruhi oleh suhu dan waktu pemanasan (Onyango et al., 2006).

Pati adalah karbohidrat kompleks yang terdiri atas dua macam polimer, yaitu amilosa dan amilopektin dalam rasio yang beragam. Kandungan amilosa pati berkisar antara $15-20 \%$ dan amilopektin 70-85\% (Polnaya dkk, 2008). Amilosa bersifat kering, kurang lengket dan cenderung memiliki kemampuan menyerap air yang tinggi (higroskopis) (Richana dan Sunarti 2004). Menurut Lucket dan Wang (2012) amilosa lebih mudah mengalami retrogradasi selama pendinginan. Amilopektin memiliki kemampuan untuk mengembang dan lengket pada proses pemanasan atau sterilisasi.

Pembentukkan miselium merupakan fase awal dalam perkembangan jamur sebelum terbentuknya pin head (primordia) atau bakal buah jamur (Ginting, Herlina, \& Tyasmoro, 2013). Miselium yang menyebar pada seluruh bagian baglog nantinya akan membentuk bintil kecil yang kemudian berkembang menjadi pin head dan akhirnya membentuk tungkai dan badan buah jamur.

Berat biomassa segar jamur tiram dipengaruhi oleh nutrisi yang terdapat pada media tanam. Semakin banyak nutrisi pada media produksi maka berat basah jamur tiram putih yang dihasilkan semakin tinggi. 
Nutrisi yang dibutuhkan berupa selulosa dan hemiselulosa. Pada umumnya serbuk gergaji kayu yang mempunyai kandungan selulosa $49 \%$, lignin $26,8 \%$, pentosa $15,6 \%$, abu $0,6 \%$ dan silica $0,2 \%$ (Martawijaya, 2005). Pada ampas sagu kandungan hemiselulosa $14,6 \%$ selulosa $36,3 \%$, lignin $9,7 \%$, silica $3,3 \%$, serat kasar $20,3 \%$, dan abu 4,6\% (Sangadji, 2008). Selulosa dan hemiselulosa berfungsi sebagai pengikat air pada media produksi jamur tiram.

Berdasarkan hasil sidik ragam
menunjukkan interaksi pada media
perlakuan. Pada media produksi perlakuan M1 memiliki produksi berat biomassa segar tertinggi dengan nilai rata-rata 82 gram. Pada perlakuan M1 tidak ada penambahan ampas sagu, karena semakin banyak penambahan ampas sagu akan mempengaruhi jumlah tubuh buah dan berat segar jamur tiram.

Sedangkan berat biomassa segar pada perlakuan M2 (media produksi dengan penambahan ampas sagu 10\%) memiliki nilai rata-rata yaitu 54,67 gram, M3 (media produksi dengan penambahan ampas sagu $20 \%$ ) memiliki nilai rata-rata 51,33 gram, dan M4 (media produksi dengan penambahan ampas sagu $30 \%$ ) memiliki nilai rata-rata terendah yaitu 23,33 gram.

Terdapat beberapa faktor lain yang mempengaruhi berat basah jamur tiram yaitu suhu, cahaya, dan kelembaban. Suhu optimal untuk menghasilkan berat basah yang tinggi yaitu $17-23^{\circ} \mathrm{C}$, intensitas cahaya yang baik yaiut $60-70{ }^{\circ} \mathrm{C}$, dan kelembaban optimal berkisar $80-90^{\circ} \mathrm{C}$.

Jamur tiram adalah jamur yang memilki kandungan air yang tinggi. Hal tersebut dapat dibuktikan hanya dengan memegan jamur tiram putih. Menurut Wahidah (2015), hampir semua jenis jamur segar memiliki kandungan air sebanyak 8595\% sedangkan pada jamur yang sudah dikeringkan hanya mengandung 5-20\%.

Berdasarkan sidik ragam hasil produksi berat biomassa kering jamur tiram memiliki berat yang berbeda pada setiap perlakuan. Pada perlakuan M1 (media produksi tanpa penambahan ampas sagu) memiliki nilai rata-rata yaitu 12,67 gram. Sedangkan untuk perlakuan M2 (media dengan penambahan ampas sagu 10\%) memiliki nilai rata-rata 7,75 gram, perlakuan M3 (media dengan penambahan ampas sagu 20\%) memiliki nilai rata-rata 5,67 gram dan perlakuan M4 (media dengan penambahan ampas sagu $30 \%$ ) memiliki nilai rata-rata 4,67 gram.

Saat jamur dilakukan pengovenan,berat jamur akan berkurang karena kadar air dalam jamur hilang. Akan tetapi, nutrisi yang terkandung dalam jamur tidak akan hilang meski dipanaskan. Oleh sebab itu jamur tetap bergizi saat diolah menjadi bahan makanan. Namun perlu diuji kandung nutrisi pada jamur yang sudah 
dihitung berat biomassa keringnya (Parlindung, 2003).

Efisiensi biologi berfungsi untuk menngukur tingkat efisiensi medium dalam mengahsilkan pertumbuhan dan produksi yang baik. Hal ini berhubungan dengan berat segar badan jamur yang dihasilkan. Pada dasarnya efisiensi biologi merupakan perbandingan dari berat segar yang dihasilkan dengan berat kering substrat dikali seratus persen (Sitompul, 2017).

Berdasarkan hasil analisis sidik ragam pada keempat perlakuan memiliki hasil efisiensi biologi yang berbeda pada setiap perlakuan. Nilai efisiensi pada perlakuan M1 dengan nilai rata-rata $28,8 \%$, nilai efisiensi biologi M2 dengan nilai rata-rata $16,8 \%$, nilai efisiensi biologi $\mathrm{M} 3$ dengan nilai ratarata $15,8 \%$, sedangkan untuk nilai efisiensi biologi terendah yaitu pada perlakuan M4 dengan nilai rata-rata $8,3 \%$.

Hasil analisis sidik ragam menunjukkan pada perlakuan M1 media produksi tanpa penambahan ampas sagu menghasilkan efisiensi biologi nyata lebih besar dibandingkan dengan perlakuan lainnya. Hal ini disebabkan pada media produksi memiliki berat segar dan berat kering yang lebih berat sehingga efisiensi biologi akan lebih tinggi.

Rendahnya nilai efisiensi biologi yang tidak mencapai standar normal $70-80 \%$ dari berat baglog diakibatkan karena pemanenan tidak dilakukan sampai akhir masa panen karena terbatasnya waktu penelitian sehingga pemanenan hanya dilakukan satu kali. Menurut Chang (1978), semakin tinggi rasio efisiensi biologi maka semakin tinggi pula produksi yang diperoleh dan semakin efisien penggunaan medium.

Jamur tiram putih merupakan jenis jamur kayu yang memiliki kandungan nutrisi lebih tinggi dibandingkan denga jenis jamur kayu lainnya. Jamur tiram putih mengandung protein, lemak, fosfor, besi, thiamin, dan riboflavin lebih tinggi dibandingkan jenis jamur lain (Jamilah, 2016).

Pengujian protein pada jamur tiram yang ditanam dengan media produksi yang diberi suplementasi ampas sagu menunjukkan kadar protein yang berbeda. Pada analisis protein hanya dua perlakuan yang diuji kadar proteinnya yaitu M1 dan M2. Hal ini disebabkan karena proses pemanenan yang tidak merata pada setiap perlakuan.

Berdasarkan analisis sidik ragam pada grafik (Gambar 4.5) hasil kadar protein pada perlakuan M2 dengan nilai rata-rata 20,5\% sedangkan perlakuan M1 memiliki nilai ratarata $15,2 \%$. Kadar protein jamur tiram pada penelitian ini menunjukkan M2 memiliki kandungan protein yang tinggi. Kadar normal jamur tiram putih pada media serbuk gergaji berkisar 18\%-20\%. Hal ini disebabkan karena adanya pencampuran serbuk kayu sebagai media produksi dan 
ampas sagu $10 \%$ sebagai suplementasi sehingga menghasilkan kadar nutrient yang lebih banyak.

Perlakuan M2 dengan komposisi serbuk gergaji, bekatul, kapur, dan ampas sagu, merupakan komposisi yang meningkatkan kandungan protein pada jamur tiram. Kandungan yang terdapat pada Ampas sagu menurut Sangadji (2008), memiliki kandungan hemiselulosa $14,6 \%$, selulosa $36,3 \%$, lignin $9,7 \%$, silica $3,3 \%$, serat kasar $20,3 \%$, dan abu 4,6\%. Menurut

\section{DAFTAR PUSTAKA / REFERENCES}

Asngad, Aminah., Suparti, Priyonggo Budi Laksono. 2011. Uji Kadar Serat, Karbohidrat, dan Sifat Organoleptik pada Pembuatan Tempe dari Bahan Dasar Kacang Merah (Vigna umbellate) dengan Penambahan Bekatul. Jurnal Penelitian Sains \& Teknologi Vol. 12. No 1: $23-36$.

Chan, S.T O.W., Lau and K.Y Cho. (19810. Cultivation and Nutritive Value of Pleurotus sojar-caju. European. J. Appl. Microbial Biotechial, $12: 58$ - 62.

Damayanti, R. W., Rosyidi, C. N., Priadythama, I., \& Aisyati, A. (2014). Alternatif Diversifikasi Pengolahan Jamur Tiram Putih ( Pleurotus Ostreatus ) menjadi Tepung Jamur. Jurnal Performa, 13(2), 127-134.

Ginting, A. R., Herlina, N., \& Tyasmoro, S. Y. (2013). Study of growth and production white oyster mushroom in sawdust an baggase substrate. Jurnal Produksi Tanaman, 1(2), 17-24.

Hariadi, N., Setyobudi, L., \& Nihayati, E. (2013). Studi Perumbuhan dan Hasil Produksi Jamur Tiram Putih (Pleurotus
Juwita dkk (2010), kandungan nutrisi yang terdapat pada ampas sagu yaitu pati sebanyak $64,4 \%$, serat kasar $14 \%$, protein kasar 3,3\%, lemak 0,3\%, dan abu 5\%. Sedangkan menurut Asngad dkk (2011), bekatul memiliki kandungan nutrisi protein 11,8 - 13,0 g, lemak $10,1-12,4 \mathrm{~g}$, serat kasar 2,3 - 3,2 g, karbohidrat 51,1 - 55,0 g, kalsium 500 - 700 mg, magnesium 600 - $700 \mathrm{mg}$, fosfor $1.000-2.200 \mathrm{mg}$, seng $1,7 \mathrm{mg}$, vitamin B1 0,3 - 1,9 mg, riboflavin $0,17-0,24 \mathrm{mg}$, niasin 22,40 - 39,90.

ostreatus) Pada Media Tumbuh Jerami Padi dan Serbuk Gergaji. Jurnal Produksi Tanaman, 1(1), 47-53.

Juwita, D. A., Suharti, N., \& Rasyid, R. (2013). Isolasi Jamur Pengurai Pati Dari Tanah Limbah Sagu. Jurnal Farmasi Andalas, 1(1), 35-41.

Kinasih, Pakarti, Arum. (2015). Pengaruh Penambahan Daun Pisang Kering (Klaras) dan Air Leri Terhadap Produktivitas Jamur Merang (Volvariella volvacea) Yang Ditanam Pada Baglog. Skripsi. Universitas Muhammadiyah Surakarta.

Luckett CR, Wang YJ. 2012. Effects of betaamylolysis on the resistant starch formation of debranched corn starches. J Agr Food Chem 60: 4751-4757. DOI: 10.1021/jf300854e.

N, Jamilah., 2016. Kandungan Kabohidrat dan Protein Jamur Tiram Putih (Pleurotus ostreatus) Pada Media Tanam Serbuk Gergaji Kayu Kemiri (Aleuritas moluccana) dan Serbuk Kayu Campuran. Jurnal Eksakta. Vol 1.

Parlindung, AK. (2003). Karakteristik Pertumbuhan dan Produksi Jamur Tiram Putih (Pleurotus ostreatus) dan Jamur Tiram Kelabu (Pleurotus sajor 
caju) Pada Baglog Alang-alang. Jurnal Natural Indonesia. Vol $5:$ 152-156.

Patmasari, Utik. Theresia, Tri Suharni dan Djumharan, Ratman, Permana. (2007). Pengaruh Penambahan Zeolit Terhadap Viabilitas Bibit Jamur Merang. Biodiversitas. 8 (1) : 27 - 33.

Polnaya FJ, Talahatu J, Marseno DW. 2008. Karakterisasi Tiga Jenis Pati Sagu (Metroxlon sp.) Hidroksipropil. Agritech 29(2) 87-95.

Riyanto, Fredi. (2010). Pembibitan Jamur Tiram (Pleurotus ostreatus) di Balai Pengembangan Tanaman Pangan dan Hortikultura (BPPTPH) Ngipiksari Sleman, Yogyakarta. Skripsi. Universitas Sebelas Maret.

Sangadji, I., Parakkasi, A., Wiryawan, K. G., \& Haryanto, B. (2008). Perubahan Nilai Nutrisi Ampas Sagu selam pada Fase Pertumbuhan Jamur Tiram Putih ( Pleurotus ostreatus ) yang berbeda ( Change of Nutritive values of Sago Meal at different growth stage of Pleurotus ostreatus ). Jurnal IImu Ternak, 8(1), 31-34.

Sitompul FT., Z Elza., Armiani., 2017. Pengaruh Berbagai Media Tumbuh dan Penambahan Gula (Skurosa) Terhadap Pertumbuhan Jamur Tiram Putih (Pleurotus ostreatus). JOM Faperta,. Vol 4 No 2.
Suparti dan Karimawati, N. (2017). Pertumbuhan Bibit F0 Jamur Tiram (Pleurotus ostreatus) dan Jamur Merang (Volvariella volvacea) Pada Media Umbi Talas Pada Konsentrasi yang Berbeda. Bioeksperimen: Jurnal Penelitian Biologi, 3(1), 64-72.

Utama, Putra., Dusep, Suhendar dan Lisa, Herlisa, Ramalia. (2013). Penggunaan Berbagai Media Dalam Pembuatan Bibit Induk Jamur Tiram Putih. Jurnal Agroteknologi. 5 (1) 45 - 53

Wardana, R., \& Erdiansyah, I. (2016). Mata Naga ( Pemanfaatan Alat dan Bahan Rumah Tangga ) Produksi Jamur tiram Generasi F0 Sampai F2 Sebagai Bahan Ajar ekstrakurikuler Budidaya Jamur tiram di SMK Raudlatul Ulum. Seminar Hasil Penelitian Dan Pengabdian Masyarakat Dana BOPTN, 307-311.

Wahidah., F. Baiq dan A.S Firman. (2015) Perbedaan Pengaruh Media Serbuk Gergaji dan Jerami Padi terhadap Pertumbuhan Jamur Tiram Putih (Pleurotus ostreatus)

Yuanita, L. (2009). Analisis Monomer Sakarida dan Gugus Fungsi Kompleks Fe-Serat Pangan pada Perebusan Kondisi Asam Analysis of Sacharide Monomer and Functional Groups of Fe- Dietary Fiber Complex at Acid Condition Boiling. Jurnal IImu Dasar, 10(1), 49-55. 